\title{
Self-Employed but Looking: A Labor Market Experiment
}

\author{
Philipp D. Koellinger Julija Mell Irene Pohl \\ Christian Roessler Theresa Treffers
}

December 6, 2012

\begin{abstract}
Empirical studies have shown that entrepreneurs earn, on average, less than the market wage for employees with otherwise similar characteristics. We examine whether having previously been self-employed is in itself a negative signal on the job market. In a field experiment where two applications of otherwise equally qualified individuals were sent for the same vacancies, we find that entrepreneurs systematically receive fewer responses than non-entrepreneurs. Thus, it appears that the earnings differential is partially explained by the fact that entrepreneurs do not have access to the reference jobs in practice. We discuss what type of unfavorable information self-employment may carry.
\end{abstract}

Keywords: self-employment; entrepreneurial incomes; occupational choice; discrimination; field experiment

JEL codes: M; C93; J62; J71; L26 


\begin{tabular}{|c|c|}
\hline \multicolumn{2}{|c|}{ ERIM Report Series Research in Management } \\
\hline ERIM Report Series reference number & ERS-2012-022-ORG \\
\hline Date of publication & $2012-12-06$ \\
\hline Version & $06-12-2012$ \\
\hline Number of pages & 51 \\
\hline Persistent URL for paper & http://hdl.handle.net/1765/38004 \\
\hline Email address corresponding author & michl@lmu.de \\
\hline Address & $\begin{array}{l}\text { Erasmus Research Institute of Management } \\
\text { (ERIM) } \\
\text { RSM Erasmus University / Erasmus School } \\
\text { of Economics } \\
\text { Erasmus University Rotterdam } \\
\text { PO Box } 1738 \\
3000 \text { DR Rotterdam, The Netherlands } \\
\text { Phone: +31104081182 } \\
\text { Fax: +31104089640 } \\
\text { Email: info@erim.eur.nl } \\
\text { Internet: http://www.erim.eur.nl }\end{array}$ \\
\hline Availability & $\begin{array}{l}\text { The ERIM Report Series is distributed } \\
\text { through the following platforms: } \\
\text { RePub, the EUR institutional repository } \\
\text { Social Science Research Network (SSRN) } \\
\text { Research Papers in Economics (RePEc) }\end{array}$ \\
\hline Classifications & $\begin{array}{l}\text { The electronic versions of the papers in the } \\
\text { ERIM Report Series contain bibliographic } \\
\text { metadata from the following classification } \\
\text { systems: } \\
\text { Library of Congress Classification (LCC) } \\
\text { Journal of Economic Literature (JEL) } \\
\text { ACM Computing Classification System } \\
\text { Inspec Classification Scheme (ICS) }\end{array}$ \\
\hline
\end{tabular}




\title{
Self-Employed but Looking: A Labor Market Experiment
}

\author{
Philipp D. Koellinger ${ }^{\mathrm{a}}$ \\ Julija Mell ${ }^{\mathrm{b}}$ \\ Irene Pohl ${ }^{\mathrm{c}}$ \\ Christian Roessler $^{\mathrm{d}}$ \\ Theresa Treffers $^{\mathrm{e}}{ }^{*}$
}

${ }^{a}$ Department of Applied Economics, Erasmus School of Economics, Erasmus University Rotterdam, Postbus 1738, 3000 DR Rotterdam, The Netherlands, T: +31 10 4082776, koellinger@ese.eur.nl

\begin{abstract}
${ }^{\mathrm{b}}$ Erasmus Research Institute of Management, Rotterdam School of Management, Erasmus University Rotterdam, Postbus 1738, 3000 DR Rotterdam, The Netherlands, T: +31 10 4081962, jmell@rsm.nl
\end{abstract}

${ }^{\mathrm{c}}$ Department of Applied Economics, Erasmus School of Economics, Erasmus University Rotterdam, Postbus 1738, 3000 DR Rotterdam, The Netherlands, T: +31 10 4082776, irene.pohl@gmx.net

\footnotetext{
${ }^{\mathrm{d}}$ Department of Economics, Faculty of Business, Economics and Statistics, University of Vienna, Hohenstaufengasse 9, 1010 Vienna, Austria, T: +43 1 427737467, christian.roessler@univie.ac.at
}
${ }^{\mathrm{e}}$ Institute for Information, Organisation and Management, Munich School of Management, Ludwig Maximilian University Munich, Ludwigstreet 28, 80539 Munich, Germany, T: +49 89 21802252, F: +49 89 21803862, michl@lmu.de

\footnotetext{
* Corresponding author. The co-authors contributed to the study as follows. Study design: PK, IP, JM. Data collection: JM, IP. Analysis: TT, PK, IP. Writing: IP, CR, TT, PK.
} 


\title{
Self-Employed but Looking: A Labor Market Experiment
}

\begin{abstract}
Empirical studies have shown that entrepreneurs earn, on average, less than the market wage for employees with otherwise similar characteristics. We examine whether having previously been self-employed is in itself a negative signal on the job market. In a field experiment where two applications of otherwise equally qualified individuals were sent for the same vacancies, we find that entrepreneurs systematically receive fewer responses than nonentrepreneurs. Thus, it appears that the earnings differential is partially explained by the fact that entrepreneurs do not have access to the reference jobs in practice. We discuss what type of unfavorable information self-employment may carry.
\end{abstract}

Keywords: self-employment, entrepreneurial incomes, occupational choice, discrimination, field experiment 


\section{Self-Employed but Looking: A Labor Market Experiment}

\section{Introduction}

When entrepreneurs say they are "not in it for the money", the data seem to support them. According to Hamilton (2000), the median earnings of entrepreneurs in the US are lower than the relevant market wage at any moment. After ten years in business, there is a 35\% gap. Provided the firm survives for 25 years, its median present value at that point is still $25 \%$ lower than the present value of future wages had one spent 25 years in a job instead. Although not all studies of entrepreneurial income paint such a bleak picture (Clark and Drinkwater, 1998; Fairlie, 2005), and time spent in self-employment may help individuals build experience and skills that could be rewarded in subsequent employment (Evans and Leighton, 1989; Kaiser and Malchow-Møller, 2011), evidence from Finland, Sweden, Japan (OECD, 1986) and Australia (Kidd, 1993) also suggests that entrepreneurs have income disadvantages compared to wage workers. These income disadvantages can be persistent even after entrepreneurs switched back to paid employment (Bruce and Schuetze, 2004; Hyytinen and Rouvinen, 2008). A recent study by Baptista et al. (2012) supports the notion of an income disadvantage for former entrepreneurs in dependent employment using a longitudinal matched employer-employee dataset. They reveal that former business owners are primarily hired by small firms who can only offer small returns to business ownership in the labor market.

In addition, entrepreneurs bear a greater income risk, which is often amplified by investments of personal funds, but they do not earn a risk premium on those assets (Moskowitz and Vissing-Jorgensen, 2002). The average return to private equity is not higher than the return to a diversified portfolio of publically traded stock. This fact is often referred to as the "private equity premium puzzle" because, given the risk involved in an 
entrepreneurial venture, the required premium over a market portfolio return has been estimated variously as 10\% (Heaton and Lucas, 2009) or more than 20\% (Benartzi, 2001). That self-employment often involves capital outlays that do not produce the required risk premium must be counted as a further cost that entrepreneurs incur, relative to taking on a job and investing in a portfolio.

It is difficult to account for such financial shortfalls other than through idiosyncratic preferences or beliefs, such as wanting to be one's own boss (Benz and Frey, 2008; Blanchflower et al., 2001) or being overly optimistic (Arabsheibani et al., 2000; Busenitz and Barney, 1997; de Meza and Southey, 1996; Fraser and Greene, 2006; Koellinger et al., 2007). But one may not expect these positive attitudes toward entrepreneurship to persist in the face of evidence that running a business is often a money-losing proposition. The missing piece, it has been suggested, is the option value of entrepreneurship: it is always possible to quit and (re-)enter employment if the venture is unsuccessful (Polkovnichenko, 2003). If future earnings potential is not at risk, then it makes good sense to test the waters and start a business that could yield large rewards (see also Hintermaier and Steinberger, 2005).

Our paper reports the results of a field experiment (Harrison and List, 2004) that was designed to examine the premise that entrepreneurs indeed have access to the same job opportunities as comparable peers who have spent their previous careers in paid employment. Over a period of a year (2011-2012), we mailed pairs of constructed CVs in response to UK job ads that differed substantively only in that one individual's experience was acquired as an employee, whereas the other had performed the same tasks in a personally owned business.

Standard theories of occupational choice assume that the employment opportunities for entrepreneurs and wage workers with otherwise similar qualifications are equal (Amit et al., 1995; Douglas and Shepherd, 2002; Evans and Leighton, 1989; Hamilton, 2000; Kihlstrom and Laffont, 1979; Kolvereid, 1996; Kolvereid and Isaksen, 2006; Lucas, 1978; van Praag 
and van Ophem, 1995). If this assumption is true, we should not find differences in employer responses to CVs of entrepreneurs and non-entrepreneurs in our field experiment.

To the best of our knowledge, this study is the first to test the equal-employmentopportunity assumption directly. This inquiry is interesting for three reasons. First, it is of practical interest whether starting a business instead of pursuing a classic career in employment has consequences for future labor market opportunities. Second, this setting is a prime candidate for a field experiment, which can reveal employer preferences that would be difficult to elicit through direct questioning. Third, testing the assumption that entrepreneurs and employees with otherwise similar qualifications have identical job market opportunities is important for the theory of occupational choice and for the interpretation of empirical results that suggest lower incomes of entrepreneurs compared to wage workers (Bruce and Schuetze, 2004; Hamilton, 2000).

Before we detail the experimental design and results, we give an overview of previous research that explains earnings differentials between entrepreneurs and employees based on pecuniary and non-pecuniary motives for becoming and staying self-employed.

\section{Background literature}

\subsection{Investment and agency}

Under wealth maximization, the expected present value of future earnings should be the same inside and outside self-employment for a given individual and effort level, but occupational differences in how income varies with performance (the earnings profile) can lead to a cross-sectional earnings differential. In the investment view, the earnings profile of the self-employed is steeper, because physical and human capital investments are not shared with an employer. The entrepreneur is fully exposed to business outcomes, whether good or bad, whereas an employee is largely insulated. The agency view, in contrast, predicts that the 
earnings profile is steeper in employment, due to incentive pay to discourage shirking (Lazear and Moore, 1984).

Empirically, entrepreneurs only have higher incomes than the employed in the upper earnings quartile. That the effort level (hours worked) of entrepreneurs increases in ownership stake and firm size (Bitler et al., 2005) lends further support to the investment view. However, the investment view would actually indicate higher average earnings in self-employment (with greater individual variability), because entrepreneurs face stronger incentives. Hence it does not account for the earnings premium in employment that we observe in reality.

\subsection{Matching, learning, and superstars}

Job seekers possess both observable and hidden skills and characteristics that may not even be apparent to themselves. From a matching and learning perspective, individuals seek an occupation in which they believe they have a comparative advantage (Roy, 1951), but may later drop out upon discovering that they are not well suited, once all the information is revealed (Jovanovic, 1982). However, this perspective is inconsistent with the previously cited evidence that many people stay in unrewarding entrepreneurial careers. Based on these models, we would expect that entrepreneurial earnings, after a sufficient period of learning, would approach and overtake employment income; but this is not the case.

Small differences in entrepreneurial ability can lead to large differences in earnings in industries where consumers are unwilling to substitute away from their preferred seller (MacDonald, 1988; Rosen, 1981). A classic example is art, where the willingness to pay for the leading master of a particular style may greatly exceed what lower-quality alternatives will fetch. Many fashion goods share this property to an extent. The higher the potential future rewards, the lower the initial pay that entrepreneurs will tolerate. At any point in time, entrepreneurial stars, those who earn high returns, exist side by side with newcomers trying 
their luck and making very little. Thus, the superstar rationale reinforces the tendency toward highly skewed earnings profiles that arise in investment and learning models. Similarly, this rationale cannot explain why average entrepreneurial incomes fail to catch up with wages in the long run, after time has shown who is a star.

\subsection{Non-pecuniary benefits}

The persistent income gap in some countries between the self-employed and the otherwise employed would be readily explained by the intangible benefits, such as independence and self-realization, that only entrepreneurship can yield. Compared with nonentrepreneurs, entrepreneurs rate pay (48\% vs. $37 \%$ ) and security (57\% vs. $32 \%)$ as less important factors in their work arrangement (Taylor, 1996). However, job satisfaction and the notion of “doing what one likes” are important incentives for entrepreneurs (Benz and Frey, 2008), as is “being one’s own boss” (Evans and Leighton, 1989). Part of the appeal of independence is flexible working hours, although Hyytinen and Ruuskanen (2007) report that entrepreneurs in fact work longer effective hours and have less leisure time than employees.

Entrepreneurs report a higher level of job satisfaction than non-entrepreneurs, independently of income (Parker, 2009), despite the fact that some are self-employed involuntarily, because they cannot find a job. The determinants of job satisfaction for the selfemployed, according to one study (Benz and Frey, 2008), are primarily autonomy and interesting tasks. The idea of procedural utility, proposed by Frey et al. (2004), reflects that workers not only value outcomes but also the conditions and processes that lead to them. In particular, people like to perform tasks that satisfy their need for autonomy (self-organizing actions), relatedness (a feeling of being connected, part of a group) and competence (controlling the environment, being effective). Benz and Frey (2008) claim that procedural 
utility can explain up to $80 \%$ of the higher job satisfaction of self-employed workers, while wage, job security and career opportunities explain only a small part of the difference.

\subsection{Risk attitude and cognitive bias}

Heterogeneous risk tolerance could also explain why some individuals choose to become and stay self-employed despite low earnings. Evidence that the self-employed are indeed less risk-averse is inconclusive (Begley and Boyd, 1987; Parker, 2009; Stewart and Roth, 2001). There is somewhat clearer support for the idea that entrepreneurs are more willing to operate in uncertain environments, i.e., are less ambiguity-averse (Begley and Boyd, 1987; Parker, 2009; Wennekers et al., 2005).

Risky choices can arise from a desire for skewness (the extent to which extremely high incomes can be earned in rare cases). Such a preference has been demonstrated for individuals who switch to self-employment (Astebro et al., 2009) and for independent inventors (Astebro, 2003; Kraus and Litzenberger, 1976), a population that is strongly related to entrepreneurs. High tolerance for skewness is likely related to the common tendency to overestimate small probabilities while underestimating large probabilities.

Other cognitive biases, such as overconfidence and over-optimism, play a role in encouraging entrepreneurs to take risks they may not perceive correctly (Arabsheibani et al., 2000; Baron, 1998; Koellinger et al., 2007; Parker, 2009) and continue to start businesses even though returns are low and industry exit rates are high (Astebro et al., 2007; Bitler et al., 2005; de Meza and Southey, 1996).

\subsection{Personal fit and discrimination}

Certain characteristics and preferences of entrepreneurs work better in the start-up environment than in traditional employment (Markman and Baron, 2003; Tett and Burnett, 
2003; Zhao et al., 2010). A past decision to enter self-employment may therefore signal to employers traits they may not desire, such as a high tolerance for risk and a preference for independence. Former entrepreneurs may be regarded as less manageable and adaptable, especially within established firms with fairly rigid protocols and hierarchical structures. Furthermore, employees in large companies may accumulate different skills and knowledge than in a similar job in self-employment, for example, as a result of different training schemes, a different corporate culture, or different customers. To the extent that companies value the skills and experiences that are specifically gained in large enterprises, entrepreneurs will be disadvantaged in the labor market if employers have the alternative to hire someone who has this specific human capital that entrepreneurs lack. This line of reasoning suggests that entrepreneurs could face difficulties in reentering the job market and that they may not be solely responsible for the decision to remain self-employed.

Disadvantages may not only arise from the employer's objective considerations of what a prior entrepreneurial career says about a candidate but could alternatively take the form of discrimination. In ordinary language, we usually refer to taste-based discrimination (List, 2007; Riach and Rich, 1991), which is to be distinguished from statistical discrimination (Arrow, 1973; Phelps, 1972). Taste-based discrimination reflects a prejudice against some attribute: in this case, employers not wanting to give a fair chance to candidates who used to be entrepreneurs.

Statistical discrimination occurs when missing information is inferred in a way that unfairly disadvantages the applicant. Recruiters are likely to rely on generalizations and stereotypes, based on characteristics they can observe: “most self-employed applicants have failed, and this is probably one of them" (when the applicant is, perhaps, a parent who quit a previous job to have a more flexible schedule). Such a reaction involves an objective use of the available information, yet may lead to mistaken judgments in particular cases. 


\section{$3 \quad$ Materials and Methods}

\subsection{Field experiments and correspondence testing}

Field experiments are used in a variety of markets to study discrimination, for example in housing (Ahmed and Hammarstedt, 2008; Baldini and Federici, 2011; Bosch et al., 2010; Hanson and Hawley, 2011), online auctions (Shohat and Musch, 2003), cars (Ayres and Sigelman, 1995), or insurance (Spencer et al., 2010). Studies of labor market discrimination typically focus on gender (Booth and Leigh, 2010; Neumark et al., 1996), race (Banerjee et al., 2009; Heath and Cheung, 2006; Kaas and Manger, 2012; Pager et al., 2009; Wood et al., 2009), age (Gringart and Helmes, 2001; Petit, 2007), or sexual orientation (Drydakis, 2009; Weichselbaumer, 2003).

Although these studies vary significantly in the treatment they test for, they generally use similar experimental designs. Two methodologies can be distinguished: a personal approach and an impersonal approach. Audit testing involves in-person interviews by coached participants with constructed backgrounds that differ only on selected dimensions. To eliminate individual appearance and bearing as a source of variability, correspondence testing is conducted in an arm's length manner, via mailed applications (for a detailed comparison between audit and correspondence testing, see Pager, 2007, and Riach and Rich, 2002). Our field experiment uses correspondence testing. Two applications that are comparable in experience, skills and education, but vary in the one aspect of interest, were sent in response to each job vacancy. Employer responses were recorded and analyzed.

Recent studies employing the correspondence testing method include testing for racial discrimination in the UK (Bertrand and Mullainathan, 2004), Germany (Kaas and Manger, 2012) and Sweden (Carlsson and Rooth, 2007); for caste and religion in India (Banerjee et al., 2009); for age in Western Australia (Gringart and Helmes, 2001) and France (Riach and Rich, 2006); and for gender and sexual orientation in Austria (Weichselbaumer, 2003). 


\subsection{Experimental setting}

Our field experiment was conducted in the UK because applications in the UK only require a $\mathrm{CV}$, whereas it is customary in many other countries to include references, certificates, and other documents in the initial application. While many field experiments that investigate biases in the labor market focus on entry-level or low-skill jobs (e.g. Booth and Leigh, 2010; Drydakis, 2009; Kaas and Manger, 2012; Pager et al., 2009), the nature of our research question required us to create applicants with considerable work experience in a profession in which both regular employment and self-employment are not uncommon. We chose human resources management as a target occupation for two reasons.

First, in order to design plausible applications, and to match them to appropriate vacancies, we needed to have a detailed understanding of the typical career trajectories, skills and experiences found in the profession, which were given in human resource management. Second, vacancies for the chosen profession and level had to open up with sufficient frequency to enable the collection of a reasonably sized dataset. This was also the case for human resource management.

Second, we chose to focus on a sector were self-employment occurs frequently and individuals with experience in working on their own account are not automatically perceived as "odd cases." UK labor market statistics show that approximately $10 \%$ of HR professionals are self-employed, so it can be assumed that recruiters have some experience with applicants who have such backgrounds. A scan of the position advertisements on online job boards revealed that a large number of vacancies for HR professionals were in the consulting business. Hence, the profile of the applicants was designed to match both HR positions in consulting and non-consulting firms. The UK labor market statistics also show that selfemployment is relatively high, at 25\%, in the occupation group "professional, scientific and 
technical activities,” which includes management and other consultancies (European

Commission, 2011). Because the consulting sector seems to have a particularly high incidence of self-employment (except for construction and agriculture, in which HR positions are rare), we tracked each vacancy as consulting or non-consulting to test for potential differences with respect to experience with applications from entrepreneurs. Thus, our experimental setting consulting and non-consulting HR jobs in the UK labor market. The same set of applications was sent in response to each vacancy.

\subsection{Applications}

\subsubsection{Curriculum Vitae}

All applications included a CV and a cover letter (see Appendix A and Appendix B for examples). To emulate a typical British CV, we studied online job boards and social media. We identified the design and range of content as well as the most relevant professional experiences, achievements, study programs, and affiliations listed. Unlike standard CVs in other countries, a British CV contains a personal statement in which the applicant gives an executive summary of the most important skills, experience, and characteristics. We constructed two master CVs, with the career trajectory up to the latest position at the bottom and the latest position and personal statement at the top.

To ensure comparability, the skills and training acquired during the first seven years, listed at the bottom of the $\mathrm{CV}$, were the same, including the level of responsibility for projects and employees at different career stages. Moreover, the pace at which the applicants had been promoted or switched jobs varied only slightly. Both types of applicants had worked at medium-sized and large firms that still exist and existed during the time the applicants were supposed to have been working there. The locations of the companies were chosen so that the applicants had no unusual episodes of moving far away in their histories. 
Both types of applicants completed a Bachelor of Science in psychology and a Master of Science in human resource management. The universities chosen offer these study tracks and have a similar reputation (University Guide, 2011). The CVs show two affiliations. While both are members of the Chartered Institute for Personnel and Development (CIPD), a qualification frequently asked for in job offers, one is additionally affiliated with a psychological society, the other with a career management association. All affiliations are common among HR professionals, as can be observed from real CVs posted on online social networks such as XING or LinkedIn.

The main variation between the two CVs was in the top part. After having moved through a total of three roles through promotions or employer changes, the fourth job title was either "Project Manager” in a known HR consultancy or "HR Consultant and Business Leader” in a personally owned consultancy. The job description and main achievements within this latest position are again very much alike, so that the only significant difference is that one has been employed and the other self-employed. The personal statement was matched to the latest position and underlined the fact of self-employment. This design ensured that the applicants remained comparable in their experience, while the difference in their occupational status was apparent at first glance.

To guarantee that the academic and professional backgrounds would be evaluated as similar, reviews were conducted with HR experts and people with extensive knowledge of the UK labor market and language. Finally, we randomized the female and male applicant names, and the design of the CV's (bottom and top, and the right-handed or left-handed CV design) throughout the data collection. This strict randomization ensures that gender, name, the specific details of past work experience and education, and the design of the CVs, all of which may influence the response rates, are not correlated with the self-employment status of the applicants. Hence, our design contained two variations (self-employed vs. employee) in four 
aspects of the CV (name, gender, background, CV design), resulting in a total of 16 different CVs, each of which was checked for language and content by UK experts.

\subsubsection{Cover letter}

We compared various sets of cover letters and CVs from British job boards, online handbooks, and ghostwriters, and identified four main parts of a cover letter: (1) a statement of the job offer one is applying for, (2) a description of one's strengths and main achievements, (3) a statement of why one is a good match for the position at hand, and (4) a brief description of one's career path. Thus, two cover letters containing these four parts were constructed by two independent writers. This procedure ensured a personal style while simultaneously disclosing the same amount of information. One cover letter stated explicitly that the applicant had been self-employed. The cover letters were matched with the corresponding CVs and the applicants’ personal details. Again, all cover letters were checked for language and content by UK labor market experts.

\subsection{Applicants}

Our job candidates varied in two main aspects: gender and occupational status. Thus, we created four fictitious applicants, female or male and self-employed or employed elsewhere. We selected names based on a list of the most common British surnames (British Surnames, 2011). These names were matched with common first names in such a way that would avoid creating an awkward combination, e.g., alliterations such as “James Jones” were avoided. The result was two pairs of applicants, Catherine Evans and George Wright and, respectively, Ann-Marie Jones and Richard Harris. In half of the applications, the first pair was self-employed and the latter was not, while in the other half the designation was reversed. 
The applications were sent out in pairs of either male self-employed and female employed elsewhere or female self-employed and male employed elsewhere. Both pairs were given an address in Manchester in a proper neighborhood, according to a guide from monster.co.uk (Monster, 2011). The street names and postal codes exist; only the street numbers are fictitious, being higher than the highest real street number. Further contact details included the applicant's e-mail address and phone number.

Online guides and personal experience indicate that no correspondence in the first phase of the job application process is handled via postal address. Therefore, we expected no mail to be sent to the fictitious addresses. The e-mail addresses were created with two of the largest free e-mail providers and they consisted of variations of the names of the applicants. Finally, we purchased online phone numbers with a Manchester area code and a voice-mail installation, to record responses via phone. We expected that recruiters would always state their names and company and who they were trying to reach when leaving a voice-mail message.

\subsection{Application procedure}

In our experimental design, we wanted to include a variation of the job type to test whether, in a profession where self-employment is encountered frequently, reactions to selfemployed applicants would differ from a profession with less exposure. Hence, we sent a similar number of applications to consulting and non-consulting firms.

A comparison of the vacancies revealed that some HR jobs carry management responsibilities, such as HR manager or HR project manager, while others do not necessarily involve responsibility for a team, such as HR business partners, HR consultants, and HRrelated specialists. The construction of the CVs allowed for applications to both types of positions, i.e., manager and non-manager positions. 
We searched for open job offers on the Internet, primarily on two major online job boards, namely simplyhrjobs.co.uk and monster.co.uk, and all applications were sent electronically via the job board or via email. Although most applications for non-consulting jobs could be processed via the two job boards, consultancies either advertised their open positions exclusively on special consultancy job boards, such as top-consultant.com, or relied on the job seekers to search on their company websites for vacancies. The application procedure for jobs posted on the consulting job board was comparable to the non-consulting job boards. Consulting companies that only advertised their positions on their own websites required the use of an online application system. All online application systems allowed uploading of a cover letter, so that there was no difference in the information supplied between the three application procedures, i.e., e-mail, job board, and online application system.

We sent 100 applications to 50 job vacancies in 2011 and another 96 applications to 48 job vacancies in 2012. We aimed to apply to an equal number of manager / non-manager and consulting / non-consulting positions, but were ultimately constrained by the available postings, so the proportions deviated somewhat (see results section). We ensured that the 16 different CVs were randomized across these positions (see Appendix C for the experimental matrix). Each vacancy received two applications as determined by the experimental matrix. The CVs and cover letters were kept unchanged from their blue prints as much as possible; however, we included matching references to specific capabilities if explicitly asked for in the job description, e.g., experience in a certain business area or language skills. To avoid identification of the pairs, the applications were sent at different times: one in the morning and the other in the afternoon. Each job application was recorded along with information about the position (title, salary, permanent / temporary) and the firm (name, location, consulting / non-consulting). 
A major challenge we encountered during the application process was the prevalent use of recruitment agencies as mediators between the firm and the applicants. These recruitment agencies did not provide the firm's name and only gave limited information about the job. Avoiding all positions handled by recruiting agencies would have forced us to exclude too many vacancies. Therefore, we have incomplete information about the employer in some cases. We ensured that any contact person in an agency only received one pair of applications.

\subsection{Measuring responses}

For every application we sent out, the response or non-response was recorded. Negative responses were never communicated via phone. Therefore, a voice mail was always categorized as an "invite.” An e-mail usually asked for an interview, for more specific information (e.g., regarding salary expectations and notice period), or stated a rejection. These responses were recorded correspondingly as either “invite” or "negative.”

Some agencies had a special response policy. If the applicant did not receive a call or email response within a week, he could consider himself rejected. For these applications, a negative indirect response was recorded after the expiration of the mentioned period.

Responses to postal addresses were not expected nor could they be processed, as the addresses were fictitious.

In the event of a positive response, the recruiters were informed politely and in a timely manner that the applicant is no longer interested. Only two applications were sent to each company, and it is likely that they only accounted for a very small share of the applications each company received, keeping the costs for the companies reasonably low. 


\section{$4 \quad$ Results}

\subsection{Descriptives and correlations}

Of the 196 applications that were sent out in total, four applications had to be excluded from the analysis because the position was placed "on hold" during the application process. Our analysis is thus based on 192 observations.

Table 1 summarizes the distribution of applications. The 192 applications have an equal number of males $(n=96)$ and females $(n=96)$, and self-employed $(n=96)$ and wage workers ( $n=96)$. Furthermore, we distinguish between positions in the consulting $(n=68)$ and nonconsulting $(\mathrm{n}=124)$ sectors, positions including management responsibility $(\mathrm{n}=102)$ and excluding management responsibility $(n=90)$, positions in London $(n=122)$ and outside London ( $\mathrm{n}=70)$, and recruitment by agency $(\mathrm{n}=136)$ and not by agency $(\mathrm{n}=66)$.

\section{INSERT TABLE 1 ABOUT HERE}

Table 2 reports the response rates and chi-squared tests for the different sub-categories of the sample. The number of observations is displayed in brackets below the corresponding percentage rates. Columns (1) and (2) contain the negative responses, distinguishing between no reaction and indirect / direct negative responses. Column (3) shows the positive responses, and column (4) collects the outcomes of the chi-squared tests for (1), (2), and (3).

The following three columns present the cases in which both applicants (column (5)), only the self-employed person (column (6)), or only the person employed elsewhere (column (7)) received a positive response. Column (8) reports a measure of net discrimination for selfemployed applicants (Kaas and Manger, 2012; Riach and Rich, 2002). A positive net discrimination ratio means the self-employed applicants receive less positive responses and vice versa. 
Half of all applications received a response. In total, 39\% were rejections and $11 \%$ invites. Across all vacancies, less than $1 \%$ of self-employed applicants received a positive response, while $6 \%$ of the regular employees did. This yields a net discrimination for selfemployed applicants of $45 \%$. The findings further reveal that the positive response rate for the self-employed is consistently lower. Differences with respect to gender, sector, managerial responsibility, location, and recruitment method also exist, but the self-employed applicant always receives a lower fraction of positive responses.

\section{INSERT TABLE 2 ABOUT HERE}

Table 3 shows correlations between the experimental variables. Due to the observed correlations, in the following regressions, we control for gender, sector, managerial responsibility, agency recruitment, place of position, name, and the order in which the applications were sent out.

INSERT TABLE 3 ABOUT HERE

\subsection{Regression Results}

We estimate a probit model to assess the effect of the various applicant-dependent and vacancy-dependent variables on the likelihood of receiving a positive response from the firms. Table 4 shows that self-employed applicants and women are at a significant disadvantage. In addition, applications in the consulting sector have a better chance of a positive response, while an invitation is much less likely for positions with managerial responsibility. 


\section{INSERT TABLE 4 ABOUT HERE}

As a robustness check, we calculated a probit regression including only those observations that actually received a negative reaction. In other words, we excluded the observations that did not receive a reply and that were previously treated as rejections. The results in Table 5 are similar to those in Table 4.

\section{INSERT TABLE 5 ABOUT HERE}

Finally, we estimated the separate probit models for male and female applicants, positions in the consulting and non-consulting sectors, with and without management responsibility, with and without agency recruitment, and for positions in and outside London. We find a significantly higher likelihood of a negative response when the self-employed applicants are male and apply for positions with managerial responsibility, via a recruitment agency, and in London. In all cases, however, being self-employed reduces the chance of receiving a positive response from a potential new employer.

\section{Discussion}

\subsection{Practical and theoretical implications}

Our results leave little room to doubt that entrepreneurs experience adverse treatment in the observed part of the UK labor market. We see three possible explanations for this finding. First, the low rate of positive responses received by entrepreneurs could be due to undesirable discrimination. In other words, employers dislike hiring former entrepreneurs for no objective 
reason. Second, self-employment may be a somewhat valid signal for employers that the candidate would not "fit” the organization. Some of the qualities that may lead to entrepreneurial success, such as a bias for change, risk-taking, and taking control, or the tendency to adopt unusual points of view, are not necessarily conducive to traditional company careers. Third, entrepreneurs may lack skills that can only be gained in employment, particularly in larger companies. For example, formal training is more frequently offered in large than in small enterprises (Alliger et al., 1997; de Kok and Uhlaner, 2001; Tracey et al., 1995). Furthermore, the type of customers HR consultants work with might differ between small entrepreneurial firms and established businesses with a brand name. Consequently, employees of a major company may have valuable skills and personal networks that someone with a self-employment background may lack.

To the extent that our results are due to undesirable discrimination, the discrimination is likely of the statistical type: certain stereotypes about the self-employed may consistently cause them to be overlooked, even though there are, in reality, many different circumstances that could have led to their situation. Typical examples would be a temporary need for flexible hours, disruption in employment because of spousal relocation or an economic downturn, or having pursued a promising business idea for its own sake, rather than personal independence. Some former entrepreneurs could be perfectly viable or even exceptional employees, but are excluded from job opportunities together with their peers.

This is where policy concerns potentially arise. Socially desirable decisions, such as experimentation with entrepreneurial ideas or dedicating time to one's family, should not be discouraged by the knowledge that it would be difficult to reenter traditional employment. These barriers could represent a significant cost of entrepreneurship. On the business side, recruiting biases against the self-employed may systematically select against the innovative capabilities these workers could bring and that are in principle much sought-after. Such biases 
arise to some extent from the need for narrow criteria in automated searches, given the large volume of applications for some positions.

The quality of recruiting is inherently difficult to benchmark and evaluate, as those who were hired cannot be compared by subsequent performance with those who were not. (In any case, the "innovativeness" of a workforce is difficult to quantify and attribute properly to human resources vs. company culture.) It is therefore possible that biases will go unaddressed, unless a conscious effort is made to promote the consideration of former entrepreneurs for positions. As with gender or racial discrimination, this is, from the company standpoint, not so much a fairness issue as an opportunity to create comparative advantage by selecting from a strong, but relatively neglected, pool of potential employees. In the case of the selfemployed, this pool is likely to offer unique capabilities that are difficult to obtain elsewhere. Up to a point, the rewards from more flexible search strategies that can identify entrepreneurs who are also a good fit with the company surely compensate for additional time commitments in recruiting.

While the negative employer reactions to entrepreneurs that we find in our data can be rationalized, the primary interest for the theoretical literature is that they exist at all. Our findings imply that we cannot assume that a reference wage, which is constructed for a given entrepreneur based on observable characteristics other than the occupational status itself, is in fact a wage that the entrepreneur could attain in the labor market. Empirical estimates that imply that entrepreneurs bypass better income opportunities in traditional employment (Hamilton, 2000) must therefore be treated with caution - even though there are some plausible and documented reasons why entrepreneurs might do so (e.g., non-pecuniary benefits, attitudes and beliefs).

There is also a general need for labor market and entrepreneurship models to reflect the role of "personal fit” (Roessler and Koellinger, 2012). In practice, occupational choice may 
not be as much of a choice as we represent it to be. When we endow agents with productivities that are independent of the work environment, theories are at odds with empirical realities and may be missing important relationships. Our experiment indicates that it is not only the supply side of the labor market (the entrepreneurs) whose choices are sensitive to personal qualities but also the demand side (the employers), who can infer such information from career histories.

\subsection{Limitations}

Our choice to investigate the research question by means of a field experiment was driven by three main considerations. First, field data on the application attempts and success rates of entrepreneurs are difficult to find. Second, an experimental design is favorable to a design that relies on self-reports because these reports may be biased for a variety of reasons (Smith, 1982). Furthermore, self-reports typically correlate with unobserved variables that also influence the outcome. An experimental design helps mitigate this unobserved variables bias by means of experimental control and randomization. Third, field experiments are preferable to laboratory experiments for our specific research question because we want to observe the job market opportunities of entrepreneurs in real life. Hence, external validity is important in our study, and field experiments fare very favorably in this aspect (Harrison and List, 2004; Levitt and List, 2009).

However, because field experiments are conducted in a natural setting, it is often difficult to repeat them to verify results (Levitt and List, 2009). We addressed this potential concern by collecting our data in the same way in the same natural setting in two batches (in 2011 and 2012). The results we report above are based on the pooled data from both batches. However, a separate analysis by batch shows qualitatively identical results, thus providing replication. 
Furthermore, another potential limitation of field experiments is that some specifics of the treatment cannot be controlled (Harrison and List, 2004). For example, one aspect we could not ensure in this study is the review of two applications of a pair by the same recruiter. However, we applied strict randomization to minimize such challenges (for more issues in field experiments, see Campbell, 1957; Campbell and Stanley, 1966; Cook and Campbell, 1979; Meyer, 1995).

Moreover, correspondence testing is subject to criticism. The vacancies that require a written application at the first stage of the recruitment process are usually "white-collar” jobs. For manual, low-wage jobs, an interview in person or on the phone is more common. This factor limits the potential validity of this study to a specific range of professions. In addition, receiving a positive response on a written application does not immediately translate into receiving a job offer, as further stages of the recruitment process, such as a personal interview, are yet to come. Additionally, the rejection of an applicant at this early stage is not entirely comparable to rejection at a later stage.

Furthermore, correspondence testing does not expose all facets of discrimination, only the decisive form of denying an applicant the opportunity to compete for a job (Riach and Rich, 1991). Because our experiment only recorded invitations to a job interview, the very first stage of the application process, we technically cannot conclude that the applicant would be hired. However, it was our objective to test the chances of former entrepreneurs in this impersonal phase of the application process, which arguably represents the greatest barrier to receiving fair consideration for a position.

Two additional limitations exist with regard to the job search. First, because we only looked for vacancies on certain online job boards and consultancy homepages, firms that do not use these media are excluded from the dataset. Large non-consulting companies that post to their own employment websites are not part of the study. This selection could only 
influence our findings if companies that advertise on their private websites discriminate against entrepreneurs to a different extent than companies that utilize job boards or if entrepreneurs have a different job search channel preference than non-entrepreneurs. We have no reason to believe that this is the case.

Second, we must consider the effect of recruitment agencies on the hiring process. On job boards, most online vacancies for experienced HR positions are posted by professional recruitment agencies that are hired by the company for help with the search. These agencies conduct the first scan of the applications and forward the most suitable candidates. While this factor can be regarded as a problem for the experiment, as firms do not directly evaluate the applications, recruitment agencies play an important role in the UK job market and their impact should not be ignored. The hiring companies give clear instructions as to which criteria applicants of interest must meet. Furthermore, most companies maintain long-term relationships with the agencies, which allow them to become well aware of the wishes of their clients and to act as true representatives for the HR personnel of the hiring firm.

Finally, we report results for a specific type of job in the UK labor market. While restricting the scope of our study is important to limit the number of possible explanations of our findings, future studies are needed to test whether our results can be replicated in different environments.

\section{Conclusion}

We show through a field experiment set in the UK labor market that entrepreneurs face difficulties in switching back to traditional employment. Employing the method of correspondence testing, two fictitious applications reflecting equal qualifications were submitted in response to each of 98 vacancies. We manipulated gender and self-employment 
status of the two candidates, randomizing all other elements of the applications. The selfemployed individual was found to systematically attract fewer interview invitations.

Our result suggests that the choice to become an entrepreneur can result in an involuntary lock-in, a factor that should be taken into account in planning one’s future career. The result also suggests that a significant share of companies deliberately choose not to hire former entrepreneurs. This preference could reflect previous negative experiences they had with hiring entrepreneurs, but it could also reflect discrimination, which could hurt the innovative capacity of companies in the long run. In any case, our result provides a new perspective on why entrepreneurs remain self-employed (Bruce and Schuetze, 2004; Hamilton, 2000) by demonstrating that the commonly assumed outside options are not necessarily available to them.

\section{REFERENCES}

Ahmed, A.M., Hammarstedt, M. (2008). 'Discrimination in the rental housing market: A field experiment on the internet', Journal of Urban Economics, Vol. 64, pp. 362-372.

Alliger, G.M., Tannenbaum, S.I., Bennett Jr., W., Traver, H., Shotland, A. (1997). ‘A metaanalysis of the relations among training criteria', Personnel Psychology, Vol. 50, pp. 341-358.

Amit, R., Muller, E., Cockburn, I. (1995). ‘Opportunity costs and entrepreneurial activity’, Journal of Business Venturing, Vol. 10, pp. 96-106.

Arabsheibani, G., de Meza, D., Maloney, J., Pearson, B. (2000). ‘And a vision appeared unto them of a treat profit: Evidence of self-deception among the self-employed', Economic Letters, Vol. 67, pp. 35-41.

Arrow, K.J. (1973). ‘The theory of discrimination', in Ashenfelter O. and Rees A. (eds.), Discrimination in Labor Markets, Princeton University Press, Princeton, pp. 3-33. 
Astebro, T. (2003). 'The return to independent invention: Evidence of unrealistic optimism, risk seeking or skewness loving?’ The Economic Journal, Vol. 113, pp. 226-239.

Astebro, T., Jeffrey, S.A., Adomdza, G.K. (2007). 'Inventor perseverance after being told to quit: The role of cognitive biases', Journal of Behavioral Decision Making, Vol. 20, pp. 253-272.

Astebro, T., Mata, J., Santos-Pinto, L. (2009). 'Preference for skew in gambling, lotteries and entrepreneurship', Paper presented at DRUID Summer Conference 2009, Copenhagen Business School, 17 - 19 June 2009.

Ayres, I., Siegelman, P. (1995). 'Race and gender discrimination in bargaining for a new car', American Economic Review, Vol. 85, pp. 304-321.

Baldini, M., Federici, M. (2011). 'Ethnic discrimination in the Italian rental housing market', Journal of Housing Economics, Vol. 20, pp. 1-14.

Banerjee, A., Bertrand, M., Datta, S., Mullainathan, S. (2009). 'Labor market discrimination in Delhi: Evidence from a field experiment', Journal of Comparative Economics, Vol. 37, pp. 14-27.

Baptista, R., Lima, F., Preto, M.T. (2012). 'How former business owners fare in the labor market? Job assignment and earnings', European Economic Review, Vol. 56, pp. 263276.

Baron, R.A. (1998). 'Cognitive mechanisms in entrepreneurship: Why and when entrepreneurs think differently than other people', Journal of Business Venturing, Vol. 13, pp. 275-294.

Begley, T.M., Boyd, D.P. (1987). ‘Psychological characteristics associated with performance in entrepreneurial firms and smaller businesses’, Journal of Business Venturing, Vol. 2, pp. 79-93. 
Benartzi, S. (2001). 'Excessive extrapolation and the allocation of 401 (k) accounts to company stock', The Journal of Finance, Vol. 56, pp. 1747-1764.

Benz, M., Frey, B. (2008). 'The value of doing what you like: evidence from the selfemployed in 23 countries’, Journal of Economic Behavior \& Organization, Vol. 68, pp. 445-455.

Bertrand, M., Mullainathan, S. (2004). ‘Are Emily and Greg more employable than Lakisha and Jamal? A field experiment on labor market discrimination', American Economic Review, Vol. 94, pp. 991-1013.

Bitler, M.P., Moskowitz, T.J., Vissing-Jorgensen, A. (2005). 'Testing agency theory with entrepreneur effort and wealth', The Journal of Finance, Vol. 60, pp. 539-576.

Blanchflower, D.G., Oswald, A., Stutzer, A. (2001). 'Latent entrepreneurship across nations’, European Economic Review, Vol. 45, pp. 680-691.

Booth, A., Leigh, A. (2010). 'Do employers discriminate by gender? A field experiment in female-dominated occupations’, Economics Letters, Vol. 107, pp. 236-238.

Bosch, M., Carnero, M.A., Farré, L. (2010). 'Information and discrimination in the rental housing market: Evidence from a field experiment', Regional Science and Urban Economics, Vol. 40, pp. 11-19.

British Surnames (2011). ‘Top British Surnames', retrieved 20.09.2012 from: http://www.britishsurnames.co.uk/lists/

Bruce, D., Schuetze, H.J. (2004). 'The labor market consequences of experience in selfemployment', Labour Economics, Vol. 11, pp. 575-598.

Busenitz, L., Barney, J. (1997). 'Differences between entrepreneurs and managers in large organizations: Biases and heuristics in strategic decision making', Journal of Business Venturing, Vol. 12, pp. 9-30. 
Campbell, D.T. (1957). 'Factors relevant to the validity of experiments in social settings', Psychological Bulletin, Vol. 54, pp. 297-312.

Campbell, D.T., Stanley, J.C. (1966). ‘Experimental and Quasi-Experimental Designs for Research', $18^{\text {th }}$ ed., Rand McNally, Chicago.

Carlsson, M., Rooth, D. (2007). 'Evidence of ethnic discrimination in the Swedish labor market using experimental data’, Labour Economics, Vol. 14, pp. 716-729.

Clark, K., Drinkwater, S. (1998). 'Ethnicity and self-employment in Britain’, Oxford Bulletin of Economics and Statistics, Vol. 60, pp. 383-407.

Cook, T.D., Campbell, D.T. (1979). 'Quasi Experimentation: Design and Analysis Issues for Field Settings', Rand McNally, Chicago.

de Kok, J., Uhlaner, L.M. (2001). 'Organization context and human resource management in the small firm’, Small Business Economics, Vol. 17, pp. 273-291.

de Meza, D., Southey, C. (1996). ‘The borrower’s curse: Optimism, finance and entrepreneurship', The Economic Journal, Vol. 106, pp. 375-386.

Douglas, E.J., Shepherd, D.A. (2002). ‘Self-employment as a career choice: Attitudes, entrepreneurial intentions, and utility maximization', Entrepreneurship Theory and Practice, Vol. 26, pp. 81-90.

Drydakis, N. (2009). 'Sexual orientation discrimination in the labour market', Labour Economics, Vol. 16, pp. 364-372.

European Commission (Eurostat, 2011). 'Employment and Unemployment (LFS)', Data/Database, Retrieved 20.09.2012 from: http://epp.eurostat.ec.europa.eu/portal/page/portal/employment_unemployment_lfs/data /database

Evans, D.S., Leighton, L.S. (1989). ‘Some empirical aspects of entrepreneurship’, American Economic Review, Vol. 79, pp. 519-535. 
Fairlie, R. (2005). 'Entrepreneurship and earnings among young adults from disadvantaged families’, Small Business Economics, Vol. 25, pp. 223-236.

Fraser, S., Greene, F.J. (2006). ‘The effects of experience on entrepreneurial optimism and uncertainty’, Economica, Vol. 73, pp. 169-192.

Frey, B., Benz, M., Stutzer, A. (2004). 'Introducing procedural utility: Not only what but also how matters', Journal of Institutional and Theoretical Economics, Vol. 160, pp. 377401.

Gringart, E., Helmes, E. (2001). 'Age discrimination in hiring practices against older adults in Western Australia: The case of accounting assistants', Australasian Journal on Ageing, Vol. 20, pp. 23-28.

Hamilton, B.H. (2000). 'Does entrepreneurship pay? An empirical analysis of the returns to self-employment', Journal of Political Economy, Vol. 108, pp. 604-631.

Hanson, A., Hawley, Z. (2011). 'Do landlords discriminate in the rental housing market? Evidence from an internet field experiment in US cities', Journal of Urban Economics, Vol. 70, pp. 99-114.

Harrison, G.W., List, J.A. (2004). 'Field experiments', Journal of Economic Literature, Vol. 42, pp. 1009-1055.

Heath, A., Cheung, S.Y. (2006). 'Ethnic penalties in the labour market: Employers and discrimination', Department for Work and Pensions, Research Report No. 341, Corporate Document Services, Leeds.

Heaton, J., Lucas, D. (2009). 'Capital structure, hurdle rates, and portfolio choiceinteractions in an entrepreneurial firm', Paper presented at the conference Household Finance and Macroeconomics, Madrid, 15 - 16 October 2009, Paper retrieved 20.09.12 from: 
http://www.bde.es/webbde/es/secciones/sobreelbanco/Conferencias/Household_Finan_ 8eed83b880bff11.html

Hintermaier, T., Steinberger, T. (2005). 'Occupational choice and the private equity premium puzzle’, Journal of Economic Dynamics \& Control, Vol. 29, pp. 1765-1783.

Hyytinen, A., Rouvinen, P. (2008). ‘The labour market consequences of self-employment spells: European evidence’, Labour Economics, Vol. 15, pp. 246-271.

Hyytinen, A., Ruuskanen, O. (2007). 'Time use of the self-employed', Kyklos, Vol. 60, pp. 105-122.

Jovanovic, B. (1982). 'Selection and the evolution of industry', Econometrica, Vol. 50, pp. 649-670.

Kaas, L., Manger, C. (2012). ‘Ethnic discrimination in Germany’s labour market: A field experiment', German Economic Review, Vol. 13, pp. 1-20.

Kaiser, U., Malchow-Møller, N. (2011). 'Is self-employment really a bad experience? The effects of previous self-employment on subsequent wage-employment wages’, Journal of Business Venturing, Vol. 26, pp. 572-588.

Kidd, M.P. (1993). 'Immigrant wage differentials and the role of self-employment in Australia’, Australian Economic Papers, Vol. 32, pp. 92-115.

Kihlstrom, R.E., Laffont, J.J. (1979). ‘A general equilibrium entrepreneurial theory of firm formation based on risk aversion', Journal of Political Economy, Vol. 87, pp. 719-749. Koellinger, P., Minniti, M., Schade, C. (2007). ’’I think I can, I think I can’: overconfidence and entrepreneurial behavior', Journal of Economic Psychology, Vol. 28, pp. 502-527.

Kolvereid, L. (1996). 'Organizational employment versus self-employment: Reasons for career choice intentions', Entrepreneurship Theory and Practice, Vol. 20, pp. 23-31.

Kolvereid, L., Isaksen, E. (2006). 'New business start-up and subsequent entry into selfemployment', Journal of Business Venturing, Vol. 21, pp. 866-885. 
Kraus, A., Litzenberger, R. (1976). 'Skewness preference and the valuation of risk assets', Journal of Finance, Vol. 31, pp. 1085-1100.

Lazear, E.P., Moore, R.L. (1984). ‘Incentives, productivity, and labor contracts’, Quarterly Journal of Economics, Vol. 99, pp. 275-296.

Levitt, S.D., List, J.A. (2009). 'Field experiments in economics: The past, the present, and the future’, European Economic Review, Vol. 53, pp. 1-18.

List, J.A. (2007). 'Field experiments: A bridge between lab and naturally-occurring data', The B.E. Journal of Economic Analysis and Policy, Vol. 5, DOI: 10.2202/1538-0637.1747.

Lucas, R.E. (1978). 'On the size distribution of business firms’, Bell Journal of Economics, Vol. 9, pp. 508-523.

MacDonald, G.M. (1988). 'The economics of rising stars', American Economic Review, Vol. 78, pp. 155-166.

Markman, G.D., Baron, R.A. (2003). 'Person-entrepreneurship fit: why some people are more successful as entrepreneurs than others', Human Resource Management Review, Vol. 13, pp. 281-301.

Meyer, B.D. (1995). 'Natural and Quasi-experiments in economics', Journal of Business \& Economic Statistics, Vol. 13, pp. 151-161.

Monster (2011). 'A guide to living in Manchester', Retrieved 20.09.2012 from: http://careeradvice.monster.co.uk/searching-for-jobs/local-job-advice/jobs.aspx

Moskowitz, T.J., Vissing-Jorgensen, A. (2002). 'The returns to entrepreneurial investment: A private equity premium puzzle’, American Economic Review, Vol. 92, pp. 745-778.

Neumark, D., Bank, R.J., van Nort, K.D. (1996). 'Sex discrimination in restaurant hiring: An audit study’, Quarterly Journal of Economics, Vol. 111, pp. 915-941.

OECD (1986). ‘Employment Outlook 1986’, OECD Publications, Paris. 
Pager, D. (2007). 'The use of field experiments for studies of employment discrimination: Contributions, critiques, and directions for the future', The Annals of the American Academy of Political and Social Sciences, Vol. 609, pp. 104-133.

Pager, D., Western, B., Bonikowski, B. (2009). 'Discrimination in a low-wage labor market: A field experiment', American Sociological Review, Vol. 74, pp. 777-799.

Parker, S. (2009). 'Evidence about the determinants of entrepreneurship’, in Parker S. (ed.), Economics of Entrepreneurship, Cambridge University Press, Cambridge, pp. 106-163. Petit, P. (2007). 'The effects of age and family constraints on gender hiring discrimination: A field experiment in the French financial sector', Labour Economics, Vol. 14, pp. 371391.

Phelps, E.S. (1972). ‘The statistical theory of racism and sexism’, American Economic Review, Vol. 62, pp. 659-661.

Polkovnichenko, V. (2003). 'Human capital and the private equity premium’, Review of Economic Dynamics, Vol. 6, pp. 831-845.

Riach, P.A., Rich, J. (1991). 'Testing for racial discrimination in the labour market', Cambridge Journal of Economics, Vol. 15, pp. 239-256.

Riach, P.A., Rich, J. (2002). 'Field experiments of discrimination in the market place', The Economic Journal, Vol. 122, pp. 480-518.

Riach, P.A., Rich, J. (2006). 'An experimental investigation of age discrimination in the French labour market', IZA - Institute for the Study of Labor, Discussion Paper No. 2522.

Roessler, C., Koellinger, P.D. (2012). ‘Entrepreneurship and organization design’, European Economic Review, Vol. 56, pp. 888-902.

Rosen, S. (1981). 'The economics of superstars', American Economic Review, Vol. 71, pp. 845-858. 
Roy, A.D. (1951). 'Some thoughts on the distribution of earnings', Oxford Economic Papers, Vol. 3, pp. 135-146.

Shohat, M., Musch, J. (2003). 'Online auctions as a research tool: A field experiment on ethnic discrimination', Swiss Journal of Psychology, Vol. 39, pp. 1164-1180.

Smith, V.L. (1982). 'Microeconomic systems as an experimental science’, American Economic Review, Vol. 72, pp. 923-955.

Spencer, M.S., Chen, J., Gee, G.C., Fabian, C.G., Takeuchi, D.T. (2010). ‘Discrimination and mental health-related service use in a national study of Asian Americans’, American Journal of Public Health, Vol. 100, pp. 2410-2417.

Stewart, W.H., Roth, P.L. (2001). 'Risk propensity differences between entrepreneurs and managers: A meta-analytic review’, Journal of Applied Psychology, Vol. 86, pp. 145153.

Taylor, M.P. (1996). 'Earnings, independence or unemployment: Why become selfemployed?’ Oxford Bulletin of Economics and Statistics, Vol. 58, pp. 253-267.

Tett, R.P., Burnett, D.D. (2003). ‘A personality trait-based interactionist model of job performance', Journal of Applied Psychology, Vol. 88, pp. 500-517.

Tracey, J.B., Tannenbaum, S.I., Kavanagh, M.J. (1995). 'Applying trained skills on the job: The importance of the work environment', Journal of Applied Psychology, Vol. 80, pp. 239-252.

The Guardian (2011). 'University League Table’, The Guardian University Guide, Retrieved 20.09.2012 from:

http://www.guardian.co.uk/education/universityguide

van Praag, C.M., van Ophem, H. (1995). 'Determinants of willingness and opportunity to start as an entrepreneur', Kyklos, Vol. 48, pp. 513-540. 
Weichselbaumer, D. (2003). 'Sexual orientation discrimination in hiring', Labour Economics, Vol. 10, pp. 629-642.

Wennekers, S., van Stel, A., Thurik, R., Reynolds, P. (2005). 'Nascent entrepreneurship and the level of economic development', Small Business Economics, Vol. 24, pp. 293-309.

Wood, M., Hales, J., Purdon, S., Sejersen, T., Hayhallar, O. (2009). 'A test for racial discrimination in recruitment practices in British cities', Department for Work and Pensions, Research Report No. 607.

Zhao, H., Seibert, S.E., Lumpkin, G.T. (2010). 'The relationship of personality to entrepreneurial intentions and performance: A meta analytic review’, Journal of Management, Vol. 36, pp. 381-404. 
Table 1: Number of observations across applicant categories ${ }^{\mathrm{a}}$

\begin{tabular}{lllcc}
\hline \multirow{2}{*}{ Gender } & & SE & Not SE & Total \\
& Male & 48 & 48 & $\mathbf{9 6}$ \\
\cline { 2 - 5 } Sector & Female & 48 & 48 & $\mathbf{9 6}$ \\
& Consulting & 34 & 34 & $\mathbf{6 8}$ \\
\cline { 2 - 5 } Manager & Non-consulting & 62 & 62 & $\mathbf{1 2 4}$ \\
\cline { 2 - 5 } & Manager & 51 & 51 & $\mathbf{1 0 2}$ \\
\hline \multirow{2}{*}{ Location } & Lon-Manager & 45 & 45 & $\mathbf{9 0}$ \\
\cline { 2 - 5 } & Non-London & 61 & 35 & $\mathbf{7 0}$ \\
\hline \multirow{2}{*}{ Recruitment } & By agency & 63 & 63 & $\mathbf{1 2 6}$ \\
\cline { 2 - 5 } & Not by agency & 33 & 33 & $\mathbf{6 6}$ \\
\hline
\end{tabular}

${ }^{\text {a }}$ se = self-employed, not se = not self-employed. 
Table 2: Response rates (numbers in parentheses), $\mathrm{Chi}^{2}$ test and net discrimination by vacancy ${ }^{\mathrm{a}}$

\begin{tabular}{|c|c|c|c|c|c|c|c|c|c|}
\hline & & $\begin{array}{c}\text { (1) } \\
\text { No } \\
\text { response }\end{array}$ & $\begin{array}{c}\text { (2) } \\
\text { Negative } \\
\text { response }\end{array}$ & $\begin{array}{l}\text { (3) } \\
\text { Positive } \\
\text { response }\end{array}$ & $\begin{array}{c}(4) \\
\text { Chi }^{2} \\
(1,2)(3)\end{array}$ & $\begin{array}{c}(5) \\
\text { Both } \\
\text { positive } \\
\text { response }\end{array}$ & $\begin{array}{l}(6) \\
\text { Only se } \\
\text { positive } \\
\text { response }\end{array}$ & $\begin{array}{c}(7) \\
\text { Only not se } \\
\text { positive } \\
\text { response }\end{array}$ & $\begin{array}{c}\text { (8) } \\
\text { Net } \\
\text { Discrimination } \\
\text { of se } \\
{[(7)-(6)] /(3)} \\
\end{array}$ \\
\hline \multirow[t]{2}{*}{ All vacancies } & & 0.50 & 0.39 & 0.11 & \multirow[t]{2}{*}{-} & 0.02 & 0.01 & 0.06 & \multirow[t]{2}{*}{0.45} \\
\hline & & $(95)$ & $(75)$ & $(22)$ & & $(4)$ & $(2)$ & (12) & \\
\hline \multirow[t]{4}{*}{ Gender } & Male & 0.46 & 0.38 & 0.16 & \multirow{4}{*}{0.07} & 0.02 & 0.01 & 0.10 & \multirow[t]{2}{*}{0.60} \\
\hline & & (44) & (37) & (15) & & $(2)$ & $(1)$ & (10) & \\
\hline & Female & 0.53 & 0.40 & 0.07 & & 0.02 & 0.01 & 0.02 & 0.14 \\
\hline & & (51) & (38) & $(7)$ & & $(2)$ & $(1)$ & $(2)$ & \\
\hline \multirow[t]{4}{*}{ Sector } & Consulting & 0.31 & 0.47 & 0.22 & \multirow{4}{*}{0.001} & 0.04 & 0.01 & 0.18 & 0.47 \\
\hline & & $(21)$ & $(32)$ & (15) & & $(3)$ & $(1)$ & $(8)$ & \\
\hline & Non- & 0.60 & 0.35 & 0.05 & & 0.01 & 0.01 & 0.03 & 0.43 \\
\hline & consulting & $(74)$ & $(43)$ & $(7)$ & & $(1)$ & $(1)$ & $(4)$ & \\
\hline \multirow{4}{*}{$\begin{array}{l}\text { Managerial } \\
\text { responsibility }\end{array}$} & Manager & 0.52 & 0.39 & 0.09 & \multirow{4}{*}{0.22} & 0.02 & 0 & 0.05 & 0.56 \\
\hline & & (53) & $(40)$ & $(9)$ & & $(2)$ & $(0)$ & $(5)$ & \\
\hline & Non- & 0.47 & 0.39 & 0.14 & & 0.02 & 0.02 & 0.08 & 0.38 \\
\hline & Manager & $(42)$ & (35) & (13) & & $(2)$ & $(2)$ & $(7)$ & \\
\hline \multirow[t]{4}{*}{ Location } & London & 0.44 & 0.44 & 0.12 & \multirow{4}{*}{0.99} & 0.02 & 0.01 & 0.07 & 0.57 \\
\hline & & (54) & $(54)$ & $(14)$ & & $(2)$ & $(1)$ & $(9)$ & \\
\hline & Non- & 0.59 & 0.30 & 0.11 & & 0.03 & 0.01 & 0.04 & 0.25 \\
\hline & London & (41) & $(21)$ & $(8)$ & & $(2)$ & $(1)$ & $(3)$ & \\
\hline \multirow[t]{4}{*}{ Recruitment } & By agency & 0.55 & 0.37 & 0.08 & \multirow{4}{*}{0.03} & 0.01 & 0 & 0.06 & 0.80 \\
\hline & & (69) & $(47)$ & $(10)$ & & $(1)$ & $(0)$ & $(8)$ & \\
\hline & Not by & 0.40 & 0.42 & 0.18 & & 0.05 & 0.03 & 0.06 & 0.17 \\
\hline & agency & $(26)$ & $(28)$ & $(12)$ & & (3) & $(2)$ & $(4)$ & \\
\hline
\end{tabular}

${ }^{\mathrm{a}}$ se $=$ self-employed, not se $=$ not self-employed. Chi $^{2}$ significance level is two-tailed 
Table 3: Correlations ${ }^{\mathrm{a}}$

\begin{tabular}{|c|c|c|c|c|c|c|c|c|c|c|c|c|c|}
\hline & response & se & gender & sector & manager & agency & place & name1 & name2 & name3 & name4 & cV_bottom & design \\
\hline se & $-0.16^{* *}$ & & & & & & & & & & & & \\
\hline gender & $-0.13^{*}$ & 0 & & & & & & & & & & & \\
\hline sector & $0.25 * * *$ & 0 & 0 & & & & & & & & & & \\
\hline manager & -0.09 & 0 & 0 & 0.04 & & & & & & & & & \\
\hline agency & $-0.15^{* *}$ & 0 & 0 & $-0.34 * * *$ & 0.02 & & & & & & & & \\
\hline place & 0.0001 & 0 & 0 & $0.29 * * *$ & $-0.15 * *$ & -0.05 & & & & & & & \\
\hline name1 & -0.09 & 0 & $-0.58 * * *$ & 0 & 0.01 & -0.04 & -0.06 & & & & & & \\
\hline name2 & -0.06 & 0 & $-0.58 * * *$ & 0 & -0.01 & 0.04 & 0.06 & $-0.33^{* * *}$ & & & & & \\
\hline name3 & -0.06 & 0 & $0.58 * * *$ & 0 & 0.01 & -0.04 & -0.06 & $-0.33 * * *$ & $-0.33 * * *$ & & & & \\
\hline name4 & $0.21^{* * *}$ & 0 & $0.58 * * *$ & 0 & -0.01 & 0.04 & 0.06 & $-0.33^{* * *}$ & $-0.33^{* * *}$ & $-0.33 * * *$ & & & \\
\hline cv_bottom & 0.03 & 0 & 0.04 & 0 & 0 & 0 & 0 & 0 & -0.05 & 0 & 0.05 & & \\
\hline design & 0.07 & 0.04 & 0 & 0 & 0 & 0 & 0 & 0.02 & -0.02 & -0.02 & 0.02 & -0.04 & \\
\hline first & -0.07 & -0.04 & $-0.21 * * *$ & 0 & 0 & 0 & 0 & $0.12 *$ & $0.12 *$ & $-0.12^{*}$ & $-0.12 *$ & 0 & $-0.38 * * *$ \\
\hline
\end{tabular}

${ }^{\mathrm{a}}$ se $=$ self-employed, name1 = Ann-Marie Jones, name2 = Catherine Evans, name3 = George Wright, name4 = Richard Harris, cv_bottom = "Leeds" (see Appendix A and B), design = design1 (see Appendix A and B), ${ }^{*} \mathrm{p}<0.10,{ }^{* *} \mathrm{p}<0.05,{ }^{* * *} \mathrm{p}<0.01$. 
Table 4: Probit regression with application response as the dependent variable ${ }^{\mathrm{a}}$

\begin{tabular}{|c|c|c|}
\hline & Coefficient & p-value \\
\hline Self-employed & -0.67 & 0.02 \\
\hline Female & -0.67 & 0.07 \\
\hline Consulting & 1.11 & 0.001 \\
\hline Managerial Responsibility & -0.46 & 0.11 \\
\hline Agency Recruitment & -0.26 & 0.37 \\
\hline London & -0.59 & 0.08 \\
\hline Name1 & -0.31 & 0.48 \\
\hline Name3 & -0.71 & 0.05 \\
\hline First application & -0.09 & 0.74 \\
\hline \multicolumn{3}{|c|}{ Model diagnostics } \\
\hline Number of observations & \multicolumn{2}{|c|}{192} \\
\hline Pseudo $\mathbf{R}^{2}$ & \multicolumn{2}{|c|}{0.23} \\
\hline $\operatorname{LR~Chi~}^{2}(6)$ & \multicolumn{2}{|c|}{31.28} \\
\hline Prob $>\mathrm{Chi}^{2}$ & \multicolumn{2}{|c|}{0.0003} \\
\hline Log likelihood & \multicolumn{2}{|c|}{-52.71} \\
\hline
\end{tabular}

\footnotetext{
${ }^{\mathrm{a}}$ Name1 = Ann-Marie Jones, Name3 = George Wright. Reference categories are not self-employed, male, non-consulting, no managerial responsibility, no agency recruitment, outside London, name2 (Catherine Evans), name4 (Richard Harris), second application. The results are robust for the exclusion of control variables.
} 
Table 5: Robustness check, probit regression with application response (negative and positive) as the dependent variable ${ }^{\mathrm{a}}$

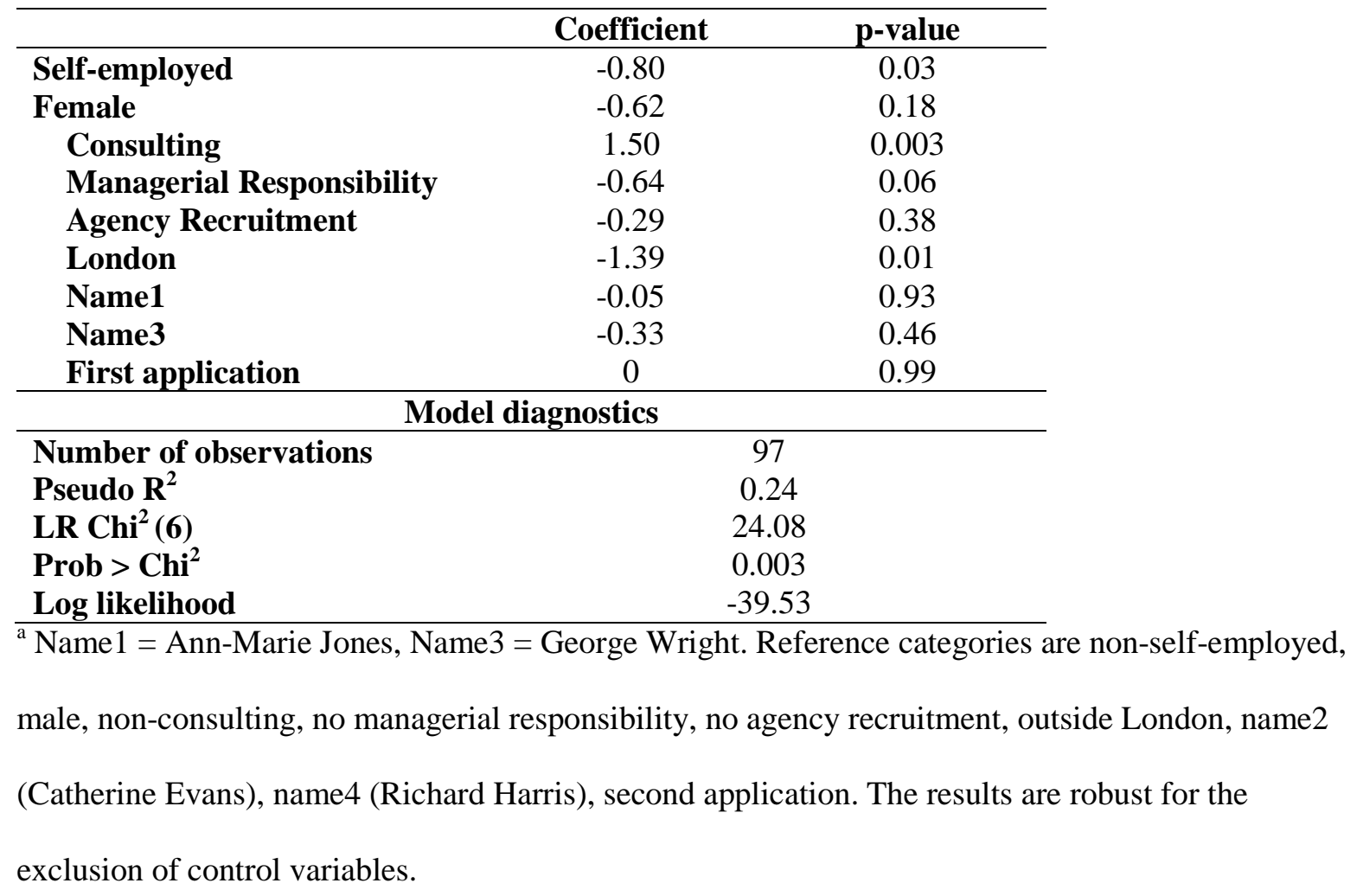




\section{APPENDIX}

Appendix A: CVs

\section{Appendix A.1: Sample CV}

self-employed, male, design $1, \mathrm{CV}$ bottom “Leeds"

George P. Wright

152 Reeves Rd

Chorlton

Manchester

M21 8DB

01614080419

georgepwright@hotmail.com

\section{Profile}

A proactive, dynamic, results-driven Human Resources professional with broad experience in all areas of HR, both as HR-Manager and main consultant and owner of an HR-consultancy. A strong HR generalist with particular strengths including: performance management, change management, and HR consultancy. Combines professional expertise with excellent interpersonal and communication skills, an outstanding project management competence and a strong business acumen.

\section{Work Experience}

HR Consultant, Business Leader

$2009-2011$

[company name], Manchester

Owned and managed a small consulting company consisting of a team of three consultants and supporting staff. Offered proactive support to a diverse set of clients over the full range of HR tasks. Provided direction and guidance during organisational changes, balancing the expectations and needs of the client organisations, their employees, stakeholders, and customers.

- Established standardised personnel selection procedures, including interviewing, testing and reference, and background checking in a variety of client companies across different industries.

- Supported a company-wide process of organisation development that addressed issues such as succession planning, superior workforce development, key employee retention, organisation design, and change management for a large telecommunications client 
company.

- Provided leadership, interviewing, and communication skills training to a range of different client groups.

\section{HR Manager (Generalist role)}

$2006-2009$

[company name], Leeds

Fulfilled HR generalist functions including recruitment and assessment, training, and management coaching. Key communicator between management and employees. Project leader on a number of initiatives for skill development and performance management.

- Established an in-house employee training system that addresses company training needs including training needs assessment, management development, the measurement of training impact, and training transfer.

- Partnered with management to communicate Human Resources policies, procedures, programmes, and laws.

- Played a key role in developing and executing performance management programmes, including $360^{\circ}$ assessments.

- Formulated job descriptions for various positions and conducted wage and compensation surveys.

- Established HR departmental measurements that support the accomplishment of the company's strategic goals.

\section{HR Generalist}

\section{HR Assistant}

[company name], Leeds

Carried out generalist HR duties such as employee recruitment and development, mediation and workplace conflict management, benefit administration, and employee record maintenance.

- Designed a new hire orientation programme that boosted productivity and cut workers' compensation costs.

- Assisted in the implementation of the performance management system that includes performance development plans and employee development programmes.

- Taught and supervised managers on the proper use of the performance management process.

- Recommended employee relations practices necessary to establish a positive employeremployee relationship and promote a high level of employee morale and motivation. 


\section{Education}

Master of Science in Human Resource Management

University of Manchester

Bachelor of Science in Psychology

University of Leeds

\section{Affiliations}

- Chartered Institute of Personnel and Development

- British Psychological Society

References are available upon request. 


\section{Appendix A.2: Sample CV non-self-employed, female, design 2, CV bottom "Birmingham"}

Ann-Marie Jones • 242 Triscombe Way • Manchester • M16 7TX

01614083694 •Jones.AMN@gmail.com

$2009-2012$

\section{Experience}

\section{Project Manager}

[company name] (HR consulting division), Manchester

Served as project manager for consulting teams providing HR services to client groups across different industries and in all HR functions. Designed, developed and initiated strategies and initiatives aligned with the needs of the client businesses. Generated a number of new client accounts.

\section{Main achievements}

- $\quad$ Devised a recruitment and talent management programme spanning the full range of expert and management positions in a large telecommunications client company.

- Led organisational assessment, diagnosis and the implementation of an organisational change initiative for a pharmaceutical client company.

- Identified initiatives, made recommendations and trained managers and directors on succession planning and competency-based selection tools in several client companies across various industries including logistics, media, and food.

\section{HR Senior Generalist,}

\section{HR Generalist}

[company name], Manchester

Provided HR generalist services such as staffing and HR diagnostics, HR development, and leadership coaching. Led several initiatives and projects across different HR functions, including training, leadership planning and performance management. Managed employee communication.

Main achievements

- $\quad$ Revised job descriptions across all levels and categories. "Shadowed" and interviewed employees to construct an accurate picture of the duties and skills required for each position.

- Developed comprehensive training programmes and seminars, which were delivered to supervisors, technical employees, and management personnel.

- Implemented a leadership planning process, including individual development plans, and performance management.

- Installed an employee suggestion programme and a yearly employee satisfaction survey.

- $\quad$ Developed a system of HR department performance indicators that serve to monitor the department's contribution to the company's goal attainment.

\section{Junior HR Representative}

[company name], Birmingham 
Fulfilled a broad range of HR functions, including staff selection, orientation, and training, monitoring of the company wage and salary structure, managing HR records, and investigating employee complaints or concerns.

Main achievements

- Played a key role in revising the standard recruitment and assessment procedure that significantly reduced early employee turnover and increased management's satisfaction with new hires.

- Trained management team on interviewing techniques and best practices, conducting workshops and one-on-one coaching sessions that contributed to sound hiring decisions.

- Assisted with the development of Human Resources policies for the company with regard to employee relations, HR procedures and laws.

- Conducted exit interviews to determine reasons behind separations.

\section{Education}

\section{Portsmouth University}

Human Resource Management (MSc)

\section{University of Birmingham}

Psychology (BSc)

\section{Affiliations}

- CIPD

- Employment Management Association (Society of Human Resource Management) 


\section{Appendix B: Cover letters}

Appendix B.1: Sample Cover Letter 1

Respective CV: self-employed, male, design 1, CV bottom "Leeds"

Dear Sir or Madam,

In response to your posting for [position] on [website], I am enclosing my $\mathrm{cv}$ for your review. Given my proven record of work performance and success as an HR generalist and consultant in different settings, I am sure I can add value to your company.

Over the course of eight years I have gained extensive experience as an HR generalist and manager in a manufacturing environment and as a consultant for various other industries. Throughout my career I have demonstrated substantial skill and expertise in all areas of HR, both operational and strategic. My main achievements have been the development and implementation of a company-wide organization development process, launching an inhouse employee training system, and aligning the HR departmental performance measures with the company's strategic goals.

In all of my roles I was not only able to apply and further develop my professional expertise, but I also displayed strong interpersonal skills and competence to lead people and to manage projects. In the latest step of my career I have founded and led a small HR consulting firm that has provided excellent service, enhancing HR standards and work productivity for my clients. However, eager to work in a continuous environment where I can see the long-term benefits of my efforts I have decided to move on.

The position you are offering presents the challenge I am seeking, since creating a department from scratch will give me the opportunity to employ all of my assets in pursuit of your company's strategic goals.

I would welcome the opportunity to further discuss the position with you during a personal meeting and look forward to hearing from you.

Yours faithfully,

George Wright 
Dear Sir or Madam,

As an accomplished HR Project Manager with more than 8 years of experience in generalist and consulting roles I am confident that I have the relevant skills and professional background for your advertised position as [position] on [website].

As I pursue new career opportunities, I am looking for a rewarding HR Consultant position that provides me with the opportunity to apply my broad knowledge and experience in designing and implementing $\mathrm{HR}$ processes and policies in company-wide projects. Supporting your client's company in the implementation and improvement of HR projects while ensuring a strong stakeholder management would be an exciting challenge that I am convinced I will be able to meet successfully.

In my latest position as Project Manager in [company name]'s HR consulting division I advised a wide range of clients in various industries on HR matters primarily involving strategic HR decision making and organizational change management. I particularly enjoyed working with clients from financial as well as other service industries.

In previous roles at [company name] and [company name] I have proved my ability to serve as a strong and reliable link between employees and management. Achievements include designing compensation and benefit schemes, improving recruitment and staffing processes, as well as implementing training programs.

I believe I can add value to your client's company in this position through my years of experience and enthusiasm for HR management. Therefore, I would welcome the opportunity to meet with you personally to discuss my qualifications and candidacy in detail.

Yours sincerely,

Ann-Marie Jones 
Appendix C: Experimental Matrix

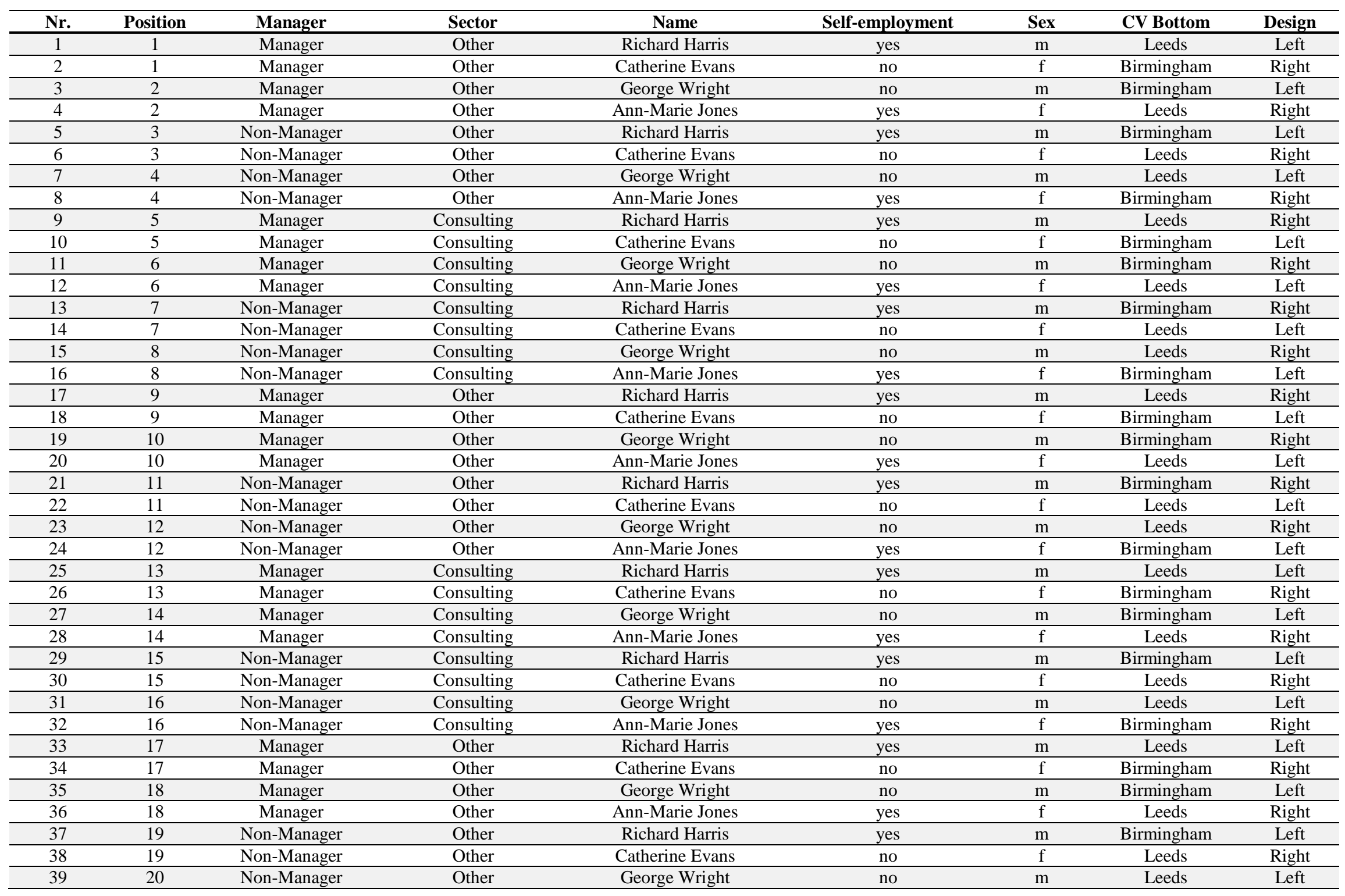




\begin{tabular}{|c|c|c|c|c|c|c|c|c|}
\hline 40 & 20 & Non-Manager & Other & Ann-Marie Jones & yes & $\mathrm{f}$ & Birmingham & Right \\
\hline 41 & 21 & Manager & Consulting & Richard Harris & yes & $\mathrm{m}$ & Leeds & Right \\
\hline 42 & 21 & Manager & Consulting & Catherine Evans & no & $\mathrm{f}$ & Birmingham & Left \\
\hline 43 & 22 & Manager & Consulting & George Wright & no & $\mathrm{m}$ & Birmingham & Right \\
\hline 44 & 22 & Manager & Consulting & Ann-Marie Jones & yes & $\mathrm{f}$ & Leeds & Left \\
\hline 45 & 23 & Non-Manager & Consulting & Richard Harris & yes & $\mathrm{m}$ & Birmingham & Right \\
\hline 46 & 23 & Non-Manager & Consulting & Catherine Evans & no & $\mathrm{f}$ & Leeds & Left \\
\hline 47 & 24 & Non-Manager & Consulting & George Wright & no & $\mathrm{m}$ & Leeds & Right \\
\hline 48 & 24 & Non-Manager & Consulting & Ann-Marie Jones & yes & $\mathrm{f}$ & Birmingham & Left \\
\hline
\end{tabular}

